\title{
Increased Serum E-Selectin Levels Were Associated with Cognitive Decline in Patients with Stroke [Corrigendum]
}

\author{
Li J, Bao J, Gao C, et al. Int J Gen Med. 2021;14:733-739
}

Page 733, Correspondence, the email address for Shujuan Tian should be sjtianydy72@163.com.

Page 734, Materials and Methods, Study Population section, $1^{\text {st }}$ sentence, "We studied 322 hospitalized patients from the first hospital of Hebei Medical University in
China because of ischemic or hemorrhagic stroke between January 2014 and August 2016" should read "We studied 322 hospitalized patients from the National Population Health Science Data center in China because of ischemic or hemorrhagic stroke between January 2014 and August 2016".

The authors apologize for these errors.

\section{Publish your work in this journal}

The International Journal of General Medicine is an international, peer-reviewed open-access journal that focuses on general and internal medicine, pathogenesis, epidemiology, diagnosis, monitoring and treatment protocols. The journal is characterized by the rapid reporting of reviews, original research and clinical studies across all disease areas. The manuscript management system is completely online and includes a very quick and fair peer-review system, which is all easy to use. Visit http://www.dovepress.com/ testimonials.php to read real quotes from published authors. 